\title{
The Moderating Effects of City Districts' Retail Attractiveness on the in-Town versus out-of-Town Shopping Decision
}

\author{
Jon Charterina \\ Professor of Marketing Research, Dept. of Business, Finance and Marketing \\ University of the Basque Country, Avda. Lehendakari Aguirre, 83, Bilbao, Spain \\ Tel: 39-94-601-7008Ｅ-mail: jon.charterina@ehu.es
}

Received: December 18, 2011 Accepted: January 4, 2012 Published: April 1, 2012

doi:10.5539/ijms.v4n2p9 URL: http://dx.doi.org/10.5539/ijms.v4n2p9

\begin{abstract}
The retail sector plays a strategic part in urban regeneration. In this sense, municipal officials need to implement plans and encourage measures that will offset the relative loss of commercial appeal to out-of-town retail zones. To achieve this, it is important that they understand how shoppers choose between two possible locations. Using logistic regression functions, this work analyses to what extent a set of four judgemental indicators in a city's different districts, forming its retail attractiveness, exerts a compensating effect by reducing the outcome of out-of-town shopping. Results confirm that retail attractiveness of districts, in interaction both with the entropy of shopping formats within the city, and with the size of the shopping basket, exerts an inhibiting effect to shopping acts in out-of-town retail areas. The study ends with recommendations for town centre managers, public authorities and private bodies towards reverting the reducing affluence of shopping acts in city centres.
\end{abstract}

Keywords: Mobility in urban centre, Spatial behavior in shopping, Urban commercial revitalization plan, Retail attractiveness

\section{Introduction}

In recent decades, there has been a steady shift in retail activity from town centres to the suburbs, creating growing competition between the two areas (Cruz Roche et al. 2002; García Escalona 1997; Hernandez and Jones 2005; Kok 2007; Marrero 1999; Molinillo 2002; Teller and Reutterer, 2008; Thomas et al. 2006; Weltevreden et al. 2005). These market forces appear to have given an advantage to out-of-town retail developments on the assumption that "bigger is better" (Phillips and Swaffin-Smith 2004). Governments at different levels have sought to introduce measures that will offset the consequences, not only for the retail sector, but also in terms of the wider implications of a loss of appeal, vitality and profitability of the towns themselves (Schiller, 1994; Timmermans et al. 1992). Municipal governments, for example, are working to promote and develop traditional retail trade, encouraging in-town shopping as part of a joint offer of culture, leisure and entertainment (Pal and Sanders, 1997; Warnaby, Bennison, Davies and Hughes, 2004; Warnaby and Davies, 1997; Zorrilla and Elizagárate, 2004), and in short, to minimise the delocalisation of the retail trade (Note 1).

For some time now it has been recognised - as numerous studies and specific evidence confirm (Association of Town Centre Management, 1994; Warnaby, 2000; Mitchell and Kirkup, 2003) - that tertiary sector activity, which includes the retail trade, plays a highly important role in developing urban marketing strategies, because of its economic and social impact.

In different countries, the commercial revitalization of town centres has been brought about by different factors; taken different forms and led to very different situations. In the case of Spain, from the beginning of the eighties the retailing industry has experienced a profound transformation, with a rise in large retail surfaces on the outskirts, initially close to the largest cities, like Madrid or Barcelona, to be followed during a second phase (still underway), by other provincial capitals and towns with a population of over 100,000 (Villarejo, 2008). Partly as a result of this situation, the Spanish parliament passed into law Organic Act 7/1996, which regulates certain retailing activities, and in particular, gives the regional autonomous communities the power to grant licences for the establishment of large retailing areas (over 2,500 square meters). Indeed, the preface to the Act states that its raison d'être is "the profound changes faced by retailing in Spain with the advent of new technologies and forms of selling" and the need to guarantee "the optimum allocation of resources through the operation of free and fair 
competition".

However, criticism against the Act and the resultant regional legislation developing it has argued that rather than promoting fair competition, these legal measures have resulted in positive discrimination in favour of established retailing formats and businesses to the detriment of newcomers. Precisely, the new Directive 2006/123/EC on services in the internal market, from the European Parliament and the Commission (better known as the Bolkestein Directive) compels Spain and other EU member states to modify part of their norms with respect to the opening of new retailing spaces and the regulation of competition.

Apart from the actions taken in the realm of the Spanish central and autonomous governments in legislation, public entities have also played an important role in the promotion of retailing and the provision of services in urban centres. Generally speaking, municipal plans for commercial revitalization start with a diagnosis of the urban, social and commercial situation of each district giving a SWOT analysis (identifying strengths, weaknesses, opportunities and threats). Based on this diagnosis a list of tasks is drawn up for the regeneration, conditioning and improvement of the urban space, pedestrianisation of streets and squares, signposting and improvement of street furniture, etc.), and a timeframe is specified for implementation and subsequent review. The diagnosis uses a series of parameters to score the current state of the district or municipality on a scale.

Understanding shoppers' behaviour allows authorities to develop the right strategies to encourage customer loyalty to urban environments, thus giving an economic and social boost to these areas and at the same time alleviating the adverse effects of a shift from a pedestrianised society to one whose mobility is based on the private car (Hajdu, 1988; Handy and Clifton, 2001; Teply, 1972). To this end, local and regional authorities along with privately-led agents, such as retail associations, must act together to foster "a unique 'bundle of benefits' for the urban location", and create "a form of differentiation by the existence of a genius loci, or unique "sense of place" for districts or cities, thus distancing them from any consideration as clone shopping centres (Warnaby, Bennison and Medway 2006, p. 168), a classification we apply to many shopping centres located both in-town and on the periphery.

This study analyses the extent to which some urban and retailing qualities from city districts interact with some basic shopping features of local residents and supposedly reduce the outflow of their shopping acts. To do this, we propose a composite factor for measuring retail attractiveness, which is made up of a number of judgemental indicators, each one reflecting a quality for residential and retail purposes in a city district. We also examine the impact of three sets of elements influencing consumers' preferences in selecting city centres over the periphery as shopping destinations: (1) the relative dispersion of shopping venues in the city centre, i.e. in-town entropy, with those outside it, i.e. out-of-town entropy, (2) the form of travel chosen by local shoppers and (3) the size of the shopping basket. These three effects are analysed by means of first-order factors of interaction with retail attractiveness (Agresti, 2002; Wrigley, 1985). In other words, our aim for this research is to determine to what extent factors of living and retailing space, in combination with the factors pertaining to the shoppers themselves, exert an influence over the decision to choose the city centre instead of the periphery. These effects are analysed indistinctively for all types of products in the following categories: Dry food, Fresh food, Clothing and Footwear, Household Items, Personal Items and Other Items (Note 2).

The next section in this study consists of a bibliographical review of work related to the choice of shopping venue and the variables most commonly used in these studies. It also lists the hypotheses of the study. The third section explains an empirical study with the sample taken, the variables used and the model under consideration and presents and argues the findings. Finally, the analysis ends with the conclusions, implications for management, limitations and future lines of research.

\section{Choice of Shopping Venue}

\subsection{Theoretical Background of Space Factors Conditioning Consumers' Preferred Place to Shop}

The literature analysing the consumer-based choice of shopping venue has looked at different perspectives such as consumer behaviour; attitudes towards out-of-town shopping centres (McGoldrick and Thompson, 1992a and 1992b) and determinants of patronage. According to Maronick's review (2007), one of the lines of research into the choice of shopping venues has traditionally centred on two models: (1) Gravitational models, for which patronage depends on the size of the shop and the distance to it (either in space or time), and (2) Models based on the consumer's perception of the shop's image.

Maronick also points to the existence of another line of research based on urban planning, with important contributions from Robertson (1995) and West and Orr (2003), who identify strategies for strengthening the town centre based on the creation of closed shopping centres, conservation of historical centres and developments in 
port areas, and a study by Maronick and Stiff (1985) who measured the impact of a specialty retail centre in the city on patronage.

Many empirical studies from very different perspectives have been conducted over recent years to try to establish relations of causality in point-of-sale choice. Pan and Zinkhan recognise that in spite of this, in many cases contradictory evidence has been put forward in terms of both the magnitude and direction of the effect of the same predictive variable (Pan and Zinkhan, 2006). They have consequently made a meta-analysis of the literature on point-of-sale patronage, identifying up to 16 antecedents, which they class into three groups: (1) product factors, related to the product and its attributes; (2) market factors, related to the seller, such as its services, the facilities it provides and the physical condition of the site; and (3) personal factors, involving the shoppers themselves, such as their demographic characteristics and their perceptions of the shopping location.

Based on this classification, we consider that a fourth set of factors should also be taken into account, namely, those involving the shopper's interaction with the retailing environment. With regard to the set of physical or space factors from a neighborhood or living area that influence consumers' outlet choice, some studies in the field have measured aspects such as the degree of retail concentration, as a proxy for spatial convenience (Reimers and Clulow 2004); the store's sales surface compared to the total sales surface of the supermarkets and hypermarkets in the neighbourhood (Verhetsel, 2005); or the degree of urbanization (Campo et al., 2000; Verhetsel, 2005).

Also with regard to the effect of environment on shoppers' reactions, the literature reviewed also suggests that a proper environment may have a positive emotional influence, resulting in increased time spent in a store, increased spending, increased unplanned purchasing and also an increase in the liking of a store (Jones, 1999). In this sense, it is presumed in this research that the presence of certain physical qualities of an urban space, such as districts, acts as an ingredient of their attractiveness, and helps reduce the use of private means of transport and the number of buying acts outside the city centres.

Traditionally many of the operational urban models derived from the Spatial Interaction Theory (Reilly, 1931) have based the notion of retail attractiveness on the concept of the gravity model. According to Reilly's principle of retail gravitation, a city's retail attractiveness from its surrounding territory is in direct proportion to its population and in inverse proportion to the square of the distance from it (Foot, 1981). A more recent exponent of this vision of attractiveness is to be seen in Huff's model, which measures it in terms of store size and the distance from stores to consumers (Huff, 1962, 1963, 1964). More recent works have identified attractiveness with population (Martin, 1982), or with the counts of retailers in a town or a shopping centre, particularly those who are most desirable to shoppers (Denis, Marsland and Cockett 2002; Dennis, 2009)

In general terms, the notion of 'retail attractiveness' in Spatial Interaction Theory has been defined by means of physical magnitudes, although some more recent works have allowed the inclusion of measures based on consumer perceptions (Teller and Reutterer, 2008) (Note 3). In our study, retail attractiveness is represented as a set of judgemental indicators referenced to the city districts. These indicators are the following: commercial centrality, retail continuity, pedestrian-friendliness, level of pedestrianisation, traffic congestion, parking availability, complementarity of offer and gravitational pull. Although these variables do not cover the entire set of spatial conditioners of consumers' decision as to where to shop, we contend that they do prove relevant as urban qualities of a district that exert an influence on the outcome of shopping trips within the city. For empirical considerations, and as explained below, all variables described here are taken together in a single factor called retail attractiveness (Note 4 ).

\subsection{Research Hypotheses}

It is plausible to expect some relationship of interaction between the means of transport used to go shopping and the level of retail attractiveness for the buyer's district, as determinants of shopping venue. There is plenty of empirical evidence from the field of Macroeconometrics showing that town dwellers tend to be selective as to the means of transport they choose depending on where they are going, particularly using discrete-choice models for applications such as mode-of-transport choice (Domencich and McFadden, 1975; Maddala 1983), and place-of-residence choice (McFadden, 1978). We pose the following hypotheses:

Hypothesis 1.1: The propensity to shop in the city centre on foot, bicycle or public transport grows as the level of retail attractiveness in the district is augmented. On the contrary, the propensity to travel outside the city decreases in the event of a higher level of retail attractiveness.

Hypothesis 1.2: Travel by private car is negatively moderated by the district's level of retail attractiveness: as the level of retail attractiveness grows, shoppers tend to use their own car less for their shopping trips to the city 
periphery.

In this regard, one of the main justifications for retail planning has been the fear that free operation of the market is likely to leave the population living or working in some inadequately served geographical areas (Davies, 1984, as cited by Guy, 2007). Inequality in access among socio-demographic groups of population should also be evidenced in the form of a different response, especially in the case of affluence to the peripheral areas, as out-of-town public transport tends to become scarcer than in the case of in-town, necessitating the use of the private car. Therefore:

Hypothesis 1.3: Travel by private car to the periphery is positively related to the income level: higher income level population groups will outflow to the periphery relatively more by private car.

In addition, shopping trips to the inner city or to its periphery tend to be affected by the moderating effect of the availability of retail formats a shopper may turn to. Since its adaptation by Wilson (1970) from the Natural to the Social Sciences to be incorporated into models of spatial interaction for the study of transportation phenomena, different measures of entropy have been proposed as a means for delimiting the effect of dispersion in any social activity of interest, be it transport, communication among peers, or other (Timmermans, 1993; Timmermans et al. 1992). Particularly, in studies on retailing, the entropy concept has been used for determining the degree of homogeneity in the proportion of consumption among different alternatives (González-Benito and González-Benito, 2001). More specifically, entropy has been used for measuring dispersion in assortment (Van Herpen and Pieters, 2002), discrepancy between perceived and real distances (Mas Ruiz, 1997), and online conversational dispersion in different locations (Godes and Mayzlin, 2004), to mention just a few examples. In our proposed model our aim is to register the dispersion between the available retail formats that exist in each of the two aforementioned shopping venues. Thus, two entropy measures are used: (1) in-town entropy, referring to the dispersion between different types of retailing formats used by a consumer which are situated in the urban area, and (2) out-of-town entropy, referring to the dispersion between different types of retailing formats used by this same consumer in the periphery of a city (Note 5).

In general, the higher the entropy level, the higher the variety of shopping destinations that an individual will frequent. In particular, for the same individual, if in-town entropy proves greater than out-of-town entropy, this will be interpreted as a sign of greater usage level of the retail offer from the urban area in detriment to the periphery. At the same time, it is expected that the retail attractiveness factor will be positively associated to in-town entropy, and that both will bring a higher tendency to do in-town compared to out-of-town shopping. Contrasting this interaction factor will allow us to determine to what extent these two antecedents counter diversity in the offer from the periphery. We therefore pose the following hypothesis:

Hypothesis 2: In general, a higher level of retail attractiveness, together with a higher level of in-town (compared to out-of-town) entropy, will be associated with a lesser propensity to shop out of town. On the contrary, when there is discrepancy between these two factors, there will be a greater propensity to shop out of town.

Finally, along with in-town entropy and the means of transport, the size of the shopping basket is a factor which is inherent to the consumer, and which may be associated in a given way with the shopping venue selected. Entropy measures have frequently been used in store-choice analysis. For example, analyzing the composition of shopping baskets has led to research into more specific issues, such as those of affinity analysis, electronic couponing, or online shopping (Rusell et al. 1999). Bell et al. (1998) found that there is a size threshold from which shoppers are prepared to accept higher fixed costs in exchange for lower variable costs resulting in lower total costs. In this situation, the larger the basket size, the more consumers are willing to incur higher fixed costs (meaning longer travelling distances) provided this brings smaller variable and total costs.

Secondly, it has been observed that shopping outlets on the periphery of cities tend to offer lower amounts of spatial, temporal and effort costs, as they provide a wider set of products and services in a relatively reduced space. This relatively higher degree of retail concentration results in a higher level of shopping convenience for the consumer, compared to the more traditional in-town shopping centers (Reimers and Clulow 2004) (Note 6). What is more: superstores and recent out-of-town retail developments "have been perceived to be leaving market towns as sleepy backwaters with little to offer" (Phillips and Swaffin-Smith 2004, p.557). It is expected that all these advantages result in a shopping basket that is, on average, larger in terms of the number of items for the case of the out-of-town shopping venues.

Following this reasoning, a higher level of retail attractiveness acts as an inhibitor of longer travelling distances to the periphery of cities. This means less total effort for consumers to combine their shopping trips near their living or working centers, and form larger baskets. As a consequence, it is expected that this positive interaction leads to an increased propensity to shop in the inner city. 
Therefore, according to this:

Hypothesis 3: The level of retail attractiveness has a moderating influence, reducing the positive relation existing between the size of a shopping basket and the decision to go to the periphery as a shopping destination. This means that the more adapted to retail use a district is, the less the average basket size that is procured from out-of-town shopping venues. On the contrary, a reduced level of retail use in the shopper's neighborhood will reinforce the positive relation between basket size and the periphery as a shopping destination.

\section{Empirical Study}

\subsection{Sample Taken}

In order to compare the hypotheses posed, a final sample of 41,463 acts of purchase was taken from a survey of 6,573 people living in Donostia-San Sebastian in 2003 (Note 7), out of a total registered population of 182,787. The total sample was subdivided into 10 districts or groupings of districts, depending on the distribution of the size of each one in the population. This sample also included surveys taken on the street, some of which were answered by people living outside the city. Given that this sub-sample has a low level of representativeness and that the specific goal of this study is to analyse the behaviour of shoppers living in the city, these people and their acts of purchase have been ignored here.

\subsection{Variables Considered in the Model}

To highlight the factors that determine in-town versus out-of-town shopping choice, we made a common analysis of the following product categories: 1) Fresh food; 2) Dry food; 3) Perfumery \& Toiletry; 4) Clothing and Footwear; 5) Household Items; 6) Personal Items, and 7) Other Items. In particular, we determined the logistic function for the total number of acts of purchase (Note 8).

The unit used is the act of purchase for a specific product. The dependent variable is dichotomous, differentiating whether the purchase was made in-town or out-of-town (in the suburbs).

The independent variables of the model are:

- Retail attractiveness, formed from a subset of the following variables obtained from the Special Retail Revitalization Plan (PERCO) by district, for the city of Donostia-San Sebastian in 2004: commercial centrality, retail continuity, pedestrian-friendliness, level of pedestrianisation, traffic congestion, parking availability, complementarity of offer and gravitational pull. Except for the gravitational pull, all these variables were scored using a 4-step scale, as follows: 1) Low; 2) Medium; 3) Medium/High; and 4) High. The rate of gravitational pull was taken directly from the PERCO study, which had allocated nine specific percentage levels, one for each district or group of districts in the city. Because of this limitation on the number of categories it was decided to compare it as an ordinal variable, i.e. in the same way as the other variables.

Prior to the formation of a single factor, a series of trials to maximize the internal consistency was followed by taking out one by one all the variables that reduce the Cronbach's alpha (1951) measure of internal coherence. This process led us to a final scale with an alpha of 0.912 , formed from the sum of the following variables: commercial centrality, retail continuity, pedestrian-friendliness and gravitational pull. The resulting factor of retail attractiveness was obtained by transforming the sum of these four variables into a dichotomous (low/high) type of measure, with the median set as threshold.

- Means of transport: The survey's initial categorical variable with its 7 response levels was collapsed into 3 forms of transport: 1) on foot or by bicycle; 2) own car, and 3) bus/train or other. The number of categories was reduced to avoid creating overly small frequencies in the cells of the resulting cross-table, and taking into account the fact that the joined categories would involve a similar degree of physical effort for the interviewee. The greatest physical effort and time is considered to be involved in travel on foot and by bicycle, followed by public transport (bus, train or other), and lastly, by private car.

- City centre entropy and peripheral entropy: According to Herniter (1973), the entropy of a system consisting of $\boldsymbol{n}$ possible states is:

$$
\mathrm{E}=-\sum_{\mathrm{i}=1}^{\mathrm{n}} p_{i} \quad \operatorname{Ln} p_{i}
$$

Where $\boldsymbol{p}_{\boldsymbol{i}}$ is the proportion of outcome $\boldsymbol{i}$ among all the $\boldsymbol{n}$ possible outcomes. In our case, $\boldsymbol{p}_{\boldsymbol{i}}$ is the proportion of items from a basket that have been bought in a single type of selling point (Note 9). As there is one entropy measure for the inner city and another for its periphery, each person in the sample brings two entropy measures. Finally, and for each consumer, a dichotomous variable gives the comparison measure resulting from both 
entropies, differentiating whether the in-town entropy measure is greater than the peripheral one, or vice versa.

- Size of the shopping basket: The measure of the basket size is the amount of items bought by a single person. This datum was transformed again into a dichotomous measure, differentiating the percentile group of the basket size in two halves, with the median set as threshold.

- Family income per person: This is an external control measure that is considered in the form of a percentile group dividing the sample in two halves.

\subsection{Approach of the Logistic Regression Model}

A binomial logistic regression function (Agresti 2002) can be defined in order to determine how shopping acts are to be classified as performed within the city or in its periphery, as a function of retail attractiveness, means of transport, the relative size of central versus peripheral entropy, and the relative size of the shopping basket. Thus, the binary dependent variable function, which expresses the likelihood of purchase in one place over another, is conditional on the vector of variables described above, together with those first-order interactions linking retail attractiveness with the other three independents variables (see Table 2). This probability function takes the following form:

$$
\pi(\mathrm{x})=\frac{e^{\beta \mathrm{x}_{\mathrm{j}}}}{1+\sum_{j=2}^{J} e^{\beta \mathrm{x}_{\mathrm{j}}}}
$$

where:

$\pi(\mathbf{x}): \operatorname{Pr}(\mathrm{Y} \mid \mathbf{x})$ expresses the conditional likelihood at $\mathbf{x}$ of making the act of purchase out of town as opposed to in-town, the option taken as the base category.

$\mathrm{Y}=\{1$ :Out-of-Town Purchase; 0: In-Town Purchase $\}$ expresses the dichotomous dependent variable.

$\boldsymbol{\beta}=\left(\alpha \beta_{1} \beta_{2} \ldots \beta_{\mathrm{P}}\right)_{1 \mathrm{XP}}$ is the vector of marginal effects of the $\mathrm{P}$ variables.

$\mathbf{x}=\left(\mathrm{x}_{1} \mathrm{x}_{2} \ldots \mathrm{x}_{\mathrm{J}}\right)_{1 \mathrm{xJ}}$ expresses the matrix of independent categorical or ordinal variables for the group of acts of purchase.

\subsection{Results Obtained}

Table 2 shows the results of the moderating effect of retail attractiveness with respect to the means of transport, the comparative entropy measure, and the measure of the basket size. Each section represents the results for each of the two halves of the sample according to the family income level per member.

The top of the table shows that the general goodness-of-fit levels obtained are intermediary for both groups. While it is true that the pseudo R-squared results should be approached with caution, and that their usefulness is often justified for choosing an optimum model from among various alternatives, the coefficients indicate adequate levels of explained variability in both groups.

As for the percentages of prediction of belonging to the group (in-town purchases as opposed to out-of-town purchases), the partial percentages obtained were at least $83.8 \%$. This means that the predictive capacity of the model obtained can be classed between acceptable and good (Agresti, 2002).

Significance levels for each beta coefficient were determined using Wald tests (Note 10). For all the factors, propensities tend to be relatively lower for the group of lowest income, meaning that this group in general travels less to shop in the periphery. However, despite these differences, in terms of what may be deduced from the signs of the effects, both groups behave in the same manner. With respect to their sign, propensities are negative (for the case of shopping trips to the periphery) if the transport means is on-foot, bicycle or public, and positive for the private car (Note 11).

For the on-foot, bicycle, and public transport cases, as retail attractiveness in the district increases, propensities respond in a mixed manner. In particular, they decrease for the case of the on-foot or bicycle options, but not for the public transport option. In this case, the public transport option initially shows a negative (positive) propensity for the out-of-town (in-town) destination, when the district's retail attractiveness is low. However, as the attractiveness of the living district increases, propensity to use public transport for shopping inside or outside the city becomes neutral (at redundant level). Therefore Hypothesis 1.1 should only be partially confirmed.

Also, and contrary to Hypothesis 1.2, the results show that, as the retailing attractiveness increases, so too does 
the propensity to use the private car for going out of town. Again, this conclusion is the same for the two sub-samples analysed. Therefore, contrary to what is evidenced with the on-foot and bicycle options, the retail attractiveness of the district in which respondents live does not seem to help restrain them from using their own car.

For the case of the differences in the coefficients between the two income groups, significantly negative differences are shown for the cases of on-foot/bicycle, own car and public transport in districts of low attractiveness, as well as the on-foot/bicycle option in highly attractively districts. This confirms that in general the lower income population tends to make less shopping trips to the periphery (Hypothesis 1.3). In particular, as regards the higher usage of the own car by higher income groups of population, this holds particularly true in the case of districts with low retail attractiveness. Although it also shows a greater usage level in the case of highly attractive districts, the difference is not significant.

With respect to the interaction between retail attractiveness and the compared in-town versus out-of-town entropy, for both income groups and for those buyers whose in-town entropy is higher, as retail attractiveness becomes higher, the propensity to buy in-town (out-of-town) becomes even greater (lower). This growth in the propensity is clear for the case of the lower-income subsample. The results therefore confirm our Hypothesis 2.

Finally, the third interaction factor that is included in our model shows in general negative propensities for out-of-town shopping venues when the size of the basket is smaller. This is in accordance with the reasoning explained above regarding the effects of fixed and variable costs for the shopper: as the basket size becomes smaller, there is less incentive to spread the fixed costs of the shopping venue. In short, as the retail attractiveness increases, if the shopping basket is small, buyers become even less (more) prone to shop out-of-town (in-town). These results confirm our Hypothesis 3. Again as in the case of comparative entropy, differences in propensities are larger within the lower income group, meaning that part of the sample shows more clearly the effect of retail attractiveness.

\subsection{Discussion of Results}

Some of the results obtained seem to confirm what has been found previously in the literature. Shoppers decide which means of transport they use depending on their shopping destination: if they are going to the city centre, therefore, they travel on foot, bicycle or by public transport. If they are going to the peripheral (planned) shopping centres, they opt for the private car. Also, the greater the retail attractiveness of the respondents' living district, the greater their propensity for on-foot or bicycle options and the less their use of public transport to travel to other in-town city areas. These two results seem obvious if we take it that shoppers tend to do more shopping in areas nearest to hand, if possible in their own living districts. However, what is not so obvious is the result of an increase in usage of the own car paralleling an increase in retail attractiveness. An alternative explanation for this may be that those shoppers who live in the main shopping (i.e. highly attractive) districts, instead of trying other in-town districts to look for the items to buy, discard them and select the peripheral planned shopping centres. Another explanation could be that highly attractive shopping districts are those lying geographically at the centre of a city, and thus at a distance from the outskirts and the periphery, making the use of the private car more necessary. However, this is not quite so for the case of Donostia-San Sebastian, a city with some inner residential areas, like Elgueta or Miraconcha, which have virtually no retail outlets.

An interesting finding with respect to the use of own car and public transport is that the lower income subsample shows clear increases in propensities, which run in parallel to an increase in retail attractiveness. When retail attractiveness is low, the higher income group uses public transport significantly less for shopping trips to the same or other districts, and the private car significantly more for travelling out of town. For this last option propensities are almost equal for shoppers living in highly attractive retailing areas.

Despite this growth in use of the private car, it seems also true for both groups that improving the attractiveness of districts fosters displacements on foot and by bicycle, helping to increase the use of more healthy and environmentally-friendly transport options.

As regards interactions with the comparative measures of entropy and basket size, again changes in propensities are more extreme for the case of the lower income group, in the sense of the reasoning of Hypotheses 2 and 3.

\section{Final Considerations, Implications and Limitations of the Study}

As the results show, the conditions of the urban infrastructure, not only influence the decision as to where to shop in an in-town versus out-of-town dichotomy. They also interact with the considered factors of means of transport, size of shopping basket and variety of types of retail outlets selected by consumers for their purchases. In a context of loss of attractiveness in favour of the new out-of-town shopping centres, municipal officials 
should counteract by carrying out a series of initiatives. First, they should focus their attention on the framework of urban development with a view to promoting accessible, continuous spaces in which pedestrian travel is given priority, for the sake of sustainability and public health (Sallis et al. 2004). While these actions are not of sufficient entity to revert the pre-eminence of the automobile as a form of access to the out-of-town retail offer, they at least do help to potentiate the use of other environmental-friendlier and healthier forms of transport. It should also be borne in mind that due to population aging and the presence of disadvantaged tiers of society in urban settings, a sector of the demand may not have any way of travelling to suburban areas to shop. It is therefore important to provide their local environment with sufficient high-quality retail provision (Guy 2007).

Secondly, authorities should take initiatives to maintain and reinforce the diversity of retail formats, and their implicit variety in the offer of products and services to be found within the urban space with the final aim of increasing consumers' in-town entropy of shopping acts. Very recent examples along these lines can be found in two cities near Donostia-San Sebastian, namely, Vitoria and Bilbao. In the first case, the municipal authorities intervened last year with a new law prohibiting the instalment of more bank offices in the city centre (Note 12). In the case of Bilbao, the recent closure of a historical coffee shop to make way for a new apartment and office building, and the resulting outrage caused among many local people compelled municipal authorities immediately to abort the operation and to force the buyer to change its building project and to include a viability plan.

Thirdly, it is vital that regional and municipal authorities strengthen collaboration efforts with private entities and that this web of ties grow in complexity and richness. For example, it is necessary to promote a more intensive work from the structure of the retail supply itself, by offering services that facilitate and prioritise shopping in urban areas - such as home deliveries, left-luggage services, etc. Similarly, and although they are not explicitly addressed in this study, other variables also need to be taken into account that may encourage shoppers to urban nuclei as opposed to the suburbs. These include promotional activities of the city, entertainment and the procurement of a perception of safety, among others.

Fourthly, stress must be put on the fact that although the solutions for some of the problems of the retail industry in the cities may lie partly in understanding some variables that are abstract and extensible to many different cases -such as the one studied here of retail concentration, retail entropy or the size of shopping basket- cities face space and social restrictions for which solutions tend to be unique and difficult to copy elsewhere. For example, whereas in many British cities the means of making urban centres more retail friendly has been to build new shopping malls (Guy 2007), in the case of Spanish cities, scarcity of urban space and a legal framework that favoured established competitors forced promoters of large-scale schemes to opt for the periphery. The new changes in EU legislation, mentioned above, will almost certainly bring changes in the near future in the form of new concurrence between established retailers and newcomers.

Finally, we should mention some aspects of the empirical work that may restrict the possibilities of extrapolating the conclusions more widely. The first of these is the geographical area in which the data for analysis was gathered: the city of Donostia-San Sebastián, located on the Cantabrian coast with geographical conditions in the surrounding area that need to be taken into account when examining the type of transport to be used in out-of-town shopping. Secondly, as already mentioned, the study only looks at acts-of-purchase by city dwellers and not visitors. Therefore, a more complete analysis should incorporate the resulting inflow of consumers from other places and weigh them against the phenomenon analyzed here of the outflow of inhabitants.

\section{References}

Agresti, A. (2002). Categorical Data Analysis. New Jersey: John Wiley \& Sons. http://dx.doi.org/10.1002/0471249688

Association of Town Centre Management. (1994). The effectiveness of Town Centre - Research Study. London: Association of Town Centre Management.

Bell, D.R., Ho, T.-H., \& Tang, C. (1998). Determining Where to Shop: Fixed and Variable Costs of Shopping. Journal of Marketing Research, 35(3), 352-369. [Online] Available: http://www.jstor.org/stable/3152033

Brame, R., Paternoster, R., Mazerolle, P., \& Piquero, A. (1998). Testing for the Equality of Maximum-Likelihood Regression Coefficients Between Two Independent Equations. Journal of Quantitative Criminology, 14 (3), 245-261. http://dx.doi.org/10.1023/A:1023030312801

Campo, K., Grisbrechts, E., Goossens, T., \& Verhetsel, A. (2000). The impact of location factors on the attractiveness and optimal space shares of product categories. International Journal of Research in Marketing, 17, 255-279. http://dx.doi.org/10.1016/S0167-8116(00)00026-4 
Cronbach, L.J. (1951). Coefficient alpha and the internal structure of tests, Psychometrika, 16, 297-334. http://dx.doi.org/10.1007/BF02310555

Cruz Roche, I. (Coord.), Campayo, C., Medina, O., and Rebollo, A. (2002). El impacto del supermercado sobre el comercio urbano de proximidad. Cuadernos de Asedas, 3. Madrid: Asedas.

Dennis, C. (2009). Flagship shopping centres, Chapter 6 from Kent, T. and Brown, R. (Eds.). Flagship Marketing. Concepts and Places. Oxon, UK: Routledge. 74-90.

Dennis, C., Marsland, D., \& Cockett, T. (2002). Central place practice: shopping centre attractiveness measures, hinterland boundaries and the UK retail hierarchy. Journal of Retailing and Consumer Services, 9, 185-199. http://dx.doi.org/10.1016/S0969-6989(01)00021-2

Domencich, T., \& Mc Fadden, D. (1975). Urban Travel Demand: A Behavioral Analysis. Amsterdam: North Holland.

Foot, D. (1981). Operational Urban Models. New York: Methuen.

García Escalona, E. (1997). Espacio central y actividad comercial. Distribución y Consumo, № 34, (Junio-Julio). $11-21$.

Godes, D., and Mayzlin, D. (2004). Using Online Conversations to Study Word-of-mouth Communication. Marketing Science, 23(4), 545-560. http://dx.doi.org/10.1287/mksc.1040.0071

González-Benito, O., \& González-Benito J. (2001). Estrategias de cobertura espacial del mercado español de las cadenas líderes de hipemercados. Información Comercial Española, № 789 (Diciembre-Enero), 139-151.

Guy, C. (2007). Planning for Retail Development. A critical view on the British experience. London: Routledge.

Hajdu, J.G. (1988). Pedestrian Malls in West Germany: Perceptions of Their Role. Journal of the American Planning Association, 54(3), 325-335. http://dx.doi.org/10.1080/01944368808976493

Hallsworth, A. (1988). Downtown in Canada: Innovations in Shopping. Retail \& Distribution Management, 16(4) (July/August), 26-28. http://dx.doi.org/10.1108/eb018380

Handy, S.L., \& Clifton, K.J. (2001). Local shopping as a strategy for reducing automobile travel. Transportation, 28(4), 317. http://dx.doi.org/10.1023/A:1011850618753

Herniter, J.D. (1973). An Entropy Model of Brand Purchase Behavior. Journal of Marketing Research, 10(4) (November), 361-375. [Online] Available: http://www.jstor.org/stable/3149383

Huff, D.L. (1962). A Note on Limitations of Interurban Gravity Model. Land Economics, 62(1), 64-66. http://dx.doi.org/10.2307/3144725

Huff, D.L. (1963). A probabilistic analysis of shopping centre trade areas. Land Economics, 39(1), 81-90. http://dx.doi.org/10.2307/3144521

Huff, D.L. (1964). Defining and estimating a trade area. Journal of Marketing, 28(3), 34-38. http://dx.doi.org/10.2307/1249154

Jones, M. (1999). Entertaining Shopping Experiences: An Exploratory Investigation. International Journal of Retail and Consumer Services, 6(3), 129-139. http://dx.doi.org/10.1016/S0969-6989(98)00028-9

Kok, H. (2007). Restructuring retail property markets in Central Europe: impacts on urban space. Journal of Housing and the Built Environment 22(1) (March), 107-126. http://dx.doi.org/10.1007/s10901-006-9068-z

Maddala. G.S. (1983). Limited Dependent and Qualitative Variables in Econometrics. Cambridge, UK: Cambridge University Press.

Maronick, T.J. (2007). Specialty retail centre's impact on downtown shopping, dining and entertainment. International Journal of Retail \& Distribution Management, $35(7), \quad 556$ - 568. http://dx.doi.org/10.1108/09590550710755930

Maronick, T.J., \& Stiff, R. (1985). The impact of a specialty retail centre on downtown shopping behaviour. Journal of the Academy of Marketing Science, 13(3), 292 - 306. http://dx.doi.org/10.1007/BF02729951

Marrero, J.L. (1999). Comercio y Ciudad: Una nueva relación. Comprar y vivir en el Siglo XXI. Distribución y Consumo, 46 (Junio-Julio), 120-127.

Martin, P.G. (1982). Shopping Centre Management. London: Spon Press.

Mas Ruiz, F.J. (1997). Image of Suburban Shopping Malls and Two-stage Versus Uni-equational Modelling of 
the Retail Trade Attraction. An Empirical Application. European Journal of Marketing, 33(5/6), 512-530. http://dx.doi.org/10.1108/03090569910262071

McFadden, D. (1978). Modelling the Choice of Residential Location. Chapter from Karlkist, A., et al. (Eds.). Spatial Interaction Theory and Residential Location. Amsterdam: North Holland. 75-96.

McGoldrick, P. J., \& Thompson, M. G. (1992). Regional shopping centres: out-of-town versus in-town. Aldershot, England: Avebury.

McGoldrick, P.J., \& Thompson, M.G. (1992 b). The role of image in the attraction of the out of town centre. The International Review of Retail, Distribution and Consumer Research, 2(1), 81-98. http://dx.doi.org/10.1080/09593969200000005

Mitchell, A., \& Kirkup, M. (2003). Retail development and urban regeneration: a case study of Castle Vale. International Journal of Retail \& Distribution Management, 31(9), 451-458. http://dx.doi.org/10.1108/09590550310491414

Molinillo, S. (2002). Centros Comerciales de Área Urbana. Madrid: ESIC.

NN.AA. (2003). Encuesta sobre la capacidad de gasto y su distribución en los hogares de Donostia - San Sebastián. Study conducted by Ikertalde for the Observatorio Urbano de Donostia-San Sebastián, Donostia-San Sebastián City Council.

Pal, J., \& Sanders, E. (1997). Measuring the effectiveness of town centre management schemes: an exploratory framework. International Journal of Retail \& Distribution Management, 25(6), 188 - 196. http://dx.doi.org/10.1108/09590559710160364

Pan, Y., \& Zinkhan, G. (2006). Determinants of Retail Patronage: A meta-analytical perspective. Journal of Retailing, 82(3), 229-243. http://dx.doi.org/10.1016/j.jretai.2005.11.008

Phillips, M., \& Swaffin-Smith, C. (2004). Market-towns: Victims of Market Forces? International Journal of Retail \& Distribution Management, 32(11), 557-568. http://dx.doi.org/10.1108/09590550410564782

Reilly, W.J. (1931). The Laws of Retail Gravitation. New York: Knickerbocker Press.

Reimers, V., and Clulow, V. (2004). Retail concentration: a comparison of spatial convenience in shopping strips and shopping centres. Journal of Retailing and Consumer Services, 11(4), 207-221. http://dx.doi.org/10.1016/S0969-6989(03)00038-9

Robertson, K.A. (1995). Downtown redevelopment strategies in the United States. Journal of the American Planning Association, 61(4), 429-437. http://dx.doi.org/10.1080/01944369508975655

Sallis, J.F., Frank, L.D., Saelens, B.E., \& Kraft, K. (2004). Active transportation and physical activity: opportunities for collaboration on transportation and public health research. Transportation Research Part A, 38, 249-268. http://dx.doi.org/10.1016/j.tra.2003.11.003

Schiller, R. (1994). Vitality and Viability: Challenge to the Town Centre. International Journal of Retail \& Distribution Management, 22(6), 46-50. http://dx.doi.org/10.1108/09590559410070321

Secretaria de Estado de Comercio, Turismo y Pyme. (1998). Centros Comerciales Abiertos. Dirección General de Comercio interior. Madrid: Colección de Estudios.

Teller, C., \& Reutterer, T. (2008). The evolving concept of retail attractiveness: What makes retail agglomerations attractive when customers shop at them? Journal of Retailing and Consumer Services, 15(3), 127-143. http://dx.doi.org/10.1016/j.jretconser.2007.03.003

Teply, S. (1972). Pedestrian Zone in Munich. Motivation for the Pedestrian Movement. Traffic Engineering, 43(2), 18-27.

Thomas, J.B., \& Peters, C.L.O. (2006). The underground mall: An investigation of factors influencing gray market consumption. International Journal of Retail \& Distribution Management, 34(2/3), 106-120. http://dx.doi.org/10.1108/09590550610649777

Timmermans, H. (1993). Retail Environments and Spatial Shopping Behavior. Chapter 14 from Gärling, T. \& Golledge, R.G. (Eds.). Behavior and Environment: Psychologial and Geographical Approaches. London: Elsevier.

Timmermans, H., Van Der Hagen, X., \& Borgers, A. (1992). Transportation Systems, Retail Environments and Pedestrian Trip Chaining Behaviour: Modelling Issues and Applications. Transportation Research Part B: Methodological, 26B(1), 45-59. http://dx.doi.org/10.1016/0191-2615(92)90019-S 
Van Herpen, E., \& Pieters, R. (2002). The Variety of Fan Assortment: An Extension to the Attribute-Based Approach. Marketing Science, 21(3), 331-341. [Online] Available: http://www.jstor.org/stable/1558048

Verhetsel, A. (2005). Effects of neighbourhood characteristics on store performance supermarkets versus hypermarkets. Journal of Retailing and Consumer Services, 12(2), 141-150. http://dx.doi.org/10.1016/j.jretconser.2004.11.004

Villarejo. E. (2008). Sostenibilidad y revitalización urbana: nuevas propuestas para la regulación de la implantación de los grandes establecimientos comerciales. Ciudad y Territorio. Estudios Territoriales, 40(156), 273-296.

Warnaby, G. (2000). Process, Content and Context Considerations Influencing the Marketing Urban Areas as Shopping destinations. Working Paper WP00/03. 1- 27.

Warnaby, G., \& Davies, B.J. (1997). Cities as services factories? Using the servuction system for marketing cities. International Journal of Retail \& Distribution, 25(6), 204-210.

Warnaby, G., Bennison, D., \& Medway, D. (2006). The Role of SME Retailers in Locational Differentiation. Contemporary Issues in Retail Marketing - CIRM 2006: 'Destinations and Locations: Exploring the Multiple Identities of Place' Proceedings book ( $6^{\text {th }}$ and $7^{\text {th }}$ September). 167-172.

Warnaby, G., Bennison, D., Davies, B.J., \& Hughes, H. (2004). People and partnerships: marketing urban retailing. International Journal of Retail \& Distribution, 32(11), 545-556. http://dx.doi.org/10.1108/09590550410564773

Weltevreden, J., Atzema, O., \& Frenken, K. (2005). Evolution in city centre retailing: the case of Utrecht (1974-2003). International Journal of Retail \& Distribution Management, 33(11/12), 824-841. http://dx.doi.org/10.1108/09590550510629419

West, D., \& Orr, M. (2003). Downtown malls as engines of economic development, community spirit, and political capital. Economic Development Quarterly, 17(2), $193 \quad$ - 204. http://dx.doi.org/10.1177/0891242403017002006

Wilson, A. G. (1970). Entropy in Urban and Regional Modelling. London:Pion.

Wrigley, N. (1985). Categorical Data Analysis for Geographers and Environmental Scientists. New Jersey: The Blackburn Press.

\section{Notes}

Note 1. Conclusions of the First International Conference on Urban Commerce "Urban", held in Vitoria-Gasteiz (Spain), on 27, 28 and 29 September 2006. See www.vitoria-gasteiz.org

Note 2 . This category essentially comprises a number of consumer services.

Note 3. For a comprehensive review of the literature on the notion of retail attractiveness, see this article.

Note 4. On the other hand, logistic regression analysis requires the selection of the simplest possible set of variables, seeking to eliminate redundancies that could bring a multicollinearity problem, as is the case of linear regression (Agresti, 2002).

Note 5. In particular, all the types of establishments considered for these two entropy measures are: (1) Traditional grocer's shop; (2) Traditional (non-grocer's) shop; (3) Markets selling fresh food; (4) Frozen food stores; (5) Company stores; (6) Small supermarkets; (7) Large supermarkets; (8) Hypermarkets; (9) Shopping malls; (10) Department stores; (11) Open air small markets; and (12) 'Soft' and 'Hard' discount supermarkets. For the case of the city of Donostia-San Sebastian, some of these types are exclusively present inside or outside the urban area, while others are present in both. Nevertheless, by means of the entropy measure proposed below, these differences in the number of retail formats are neutralized.

Note 6. At this point, however, it must be added that unlike the situation in many European (and especially British) cities, where recently developed in-town shopping malls are common, urban development of this type of shopping centers in Spanish cities has normally occurred in their periphery. Therefore, taking Reimers and Clulow's (2004) factor, in the case of Spanish cities the periphery shopping option entails going to shopping centres that show a higher degree of retail concentration.

Note 7. The survey was conducted by Ikertalde Grupo Consultor for Fomento de San Sebastian, a body answerable to Donostia-San Sebastian City Council. A descriptive analysis of the information is given in "Estudio de la capacidad de gasto y su distribución en los hogares donostiarras" [Study of Purchasing Power and 
its Distribution in Households in Donostia-San Sebastian], available online at

http://www.donostia.org/info/empleo/observatorio_estudios.nsf/2d66f6319b69b0bac1256bd80059a164/40cb7c7 $86417 \mathrm{a} 14 \mathrm{cc} 1256 \mathrm{e} 7 \mathrm{c003bc0a1/ \$ FILE/Estudio \% 20de \% 20la \% 20capacidad \% 20de \% 20gasto \% 20y \% 20su \% 20distri}$ buci\%C3\%B3n.pdf

Note 8 . Previously contrasts had been made differentiating by product categories, but results showed that the signs of the marginal effects in the logistic regressions had been similar. Also, in some cases there had been problems regarding the number of cases in some cells of the cross-table.

Note 9. For a list of all selling points, see note 8 .

Note 10 . The Wald statistic is a parametric test by means of which an estimated value $\hat{\theta}$ is compared to a proposed value $\hat{\theta}_{0}$ and the difference divided into the standard deviation of $\hat{\theta}$, as shown here: $t=\frac{\hat{\theta}-\hat{\theta}_{0}}{\sigma_{\hat{\theta}}}$

In order to test the significance level of the difference, the second power of the resulting value is compared to the Chi square distribution with 1 degree of freedom. This $t^{2}$ ratio applies for columns (1) and (2) of Table 2. For the case of column (3) the value to test is the significance of the difference between both coefficients (1) and (2), thus: $t_{d}=\frac{\left(\hat{\theta}_{1}-\hat{\theta}_{2}\right)-0}{\sigma_{d}}$ Therefore, the standard deviation in the denominator should be an appropriate one for the case of a comparison of two samples from mutually exclusive populations. According to Brame et al. (1998), a consistent and 'conservative' estimator for $\sigma_{d}^{2}$ is the second power of the one described in footnote ' $b$ ' of Table 2.

Note 11. In Table 2 beta coefficients are referenced to peripheral shopping. Therefore, coefficients for the case of in-town shopping would be exactly the same in absolute values, but of the opposite sign.

Note 12. "El Ayuntamiento de Vitoria limita las sucursales bancarias en el centro". El País, 8th July 2009. It can be seen on:

www.el.pais.com/articulo/pais/vasco/Ayuntamiento/Vitoria/limita/sucursales/bancarias/centro/elpepiesppvs/2009 0708elpvas_13/Tes/

Table 1. Descriptive values of the sample

\begin{tabular}{|c|c|c|}
\hline & \multicolumn{2}{|c|}{ Valid percentages } \\
\hline $\begin{array}{l}\text { Means of transport: } \\
\text { On foot/Bicycle } \\
\text { By own car } \\
\text { Public transport\&other }\end{array}$ & & $\begin{array}{l}3 \% \\
.1 \% \\
.5 \%\end{array}$ \\
\hline $\begin{array}{l}\text { Type of product: } \\
\text { Fresh food } \\
\text { Dry food } \\
\text { Perfumery \& Toiletry } \\
\text { Clothing and Footwear } \\
\text { Household Items } \\
\text { Personal Items } \\
\text { Other Items }\end{array}$ & & $\begin{array}{l}.5 \% \\
.6 \% \\
.6 \% \\
.7 \% \\
.0 \% \\
.5 \% \\
1 \% \\
\end{array}$ \\
\hline $\begin{array}{l}\text { Shopping venues: } \\
\text { In-town } \\
\text { Out-of-town }\end{array}$ & \multicolumn{2}{|c|}{$\begin{array}{l}70.3 \% \\
29.7 \%\end{array}$} \\
\hline & Mean & Standard dev. \\
\hline $\begin{array}{l}\text { Size of families } \\
\text { Monthly income per family member } \\
\text { Monthly consumption per family member } \\
\text { Monthly savings per family member } \\
\text { Size of shopping basket }\end{array}$ & $\begin{array}{l}2.79 \text { people } \\
€ 686.29 \\
€ 559.35 \\
€ 53.30 \\
21.96 \text { items }\end{array}$ & $\begin{array}{c}1.21 \\
453.37 \\
302.98 \\
101.10 \\
7.58 \\
\end{array}$ \\
\hline
\end{tabular}


Table 2. Results of adjustment and beta coefficients of the logistic functions obtained

\begin{tabular}{|c|c|c|c|}
\hline & \multicolumn{3}{|c|}{ Income Groups per family member } \\
\hline $\begin{array}{l}\text { Out-of-Town Shopping } \\
\text { (Base: In-Town Shopping) }\end{array}$ & $\begin{array}{c}\text { Group 1: } \\
\text { Below median } \\
\text { (1) }\end{array}$ & $\begin{array}{c}\text { Group 2: } \\
\text { Above median } \\
\text { (2) }\end{array}$ & (3) \\
\hline Effects of interaction & $\begin{array}{c}\beta \\
\text { (standard error) }\end{array}$ & $\begin{array}{c}\beta \\
\text { (standard error) } \\
\end{array}$ & $\begin{array}{c}\Delta \beta=(1)-(2) \\
(\text { standard error })^{\mathrm{b}}\end{array}$ \\
\hline $\begin{array}{l}\text { Goodness of fit (Pearson): } \\
\chi^{2} \\
\text { d.f. } \\
\text { Sig. }\end{array}$ & $\begin{array}{c}\mathrm{n}=19,429 \\
121.854 \\
14 \\
<0.001 \\
\end{array}$ & $\begin{array}{c}\mathrm{n}=19,859 \\
67.846 \\
14 \\
<0.001 \\
\end{array}$ & \\
\hline $\begin{array}{l}\text { Pseudo } \mathrm{R}^{2} \text { : } \\
\text { Cox and Snell } \\
\text { Nagelkerke } \\
\text { McFadden }\end{array}$ & $\begin{array}{l}0.489 \\
0.698 \\
0.557\end{array}$ & $\begin{array}{l}0.477 \\
0.681 \\
0.538 \\
\end{array}$ & \\
\hline $\begin{array}{l}\text { \% correctly classif'd: } \\
\text { In town } \\
\text { In suburbs } \\
\% \text { overall }\end{array}$ & $\begin{array}{l}91.9 \% \\
83.8 \% \\
89.6 \% \\
\end{array}$ & $\begin{array}{l}90.4 \% \\
84.8 \% \\
88.8 \% \\
\end{array}$ & \\
\hline Intersection & & & \\
\hline $\begin{array}{l}\text { RetAttractiveness*Transport: } \\
\text { Low*On foot/Bicycle }\end{array}$ & $\begin{array}{c}-4.033^{* * *} \\
(0.221) \\
\end{array}$ & $\begin{array}{c}-3.247 * * * \\
(0.180) \\
\end{array}$ & $\begin{array}{l}-0.786^{* *} \\
(0.285) \\
\end{array}$ \\
\hline Low*Car & $\begin{array}{l}0.681^{* *} \\
(0.214) \\
\end{array}$ & $\begin{array}{c}1.244 * * * \\
(0.175)\end{array}$ & $\begin{array}{l}-0.563^{*} \\
(0.276) \\
\end{array}$ \\
\hline Low*Public Tr. & $\begin{array}{c}-1.312^{* * *} \\
(0.219) \\
\end{array}$ & $\begin{array}{l}-0.458^{*} \\
(0.181) \\
\end{array}$ & $\begin{array}{c}-0.854^{* *} \\
(0.284) \\
\end{array}$ \\
\hline High*On foot/Bicycle & $\begin{array}{l}-4.225^{* * *} \\
(0.133) \\
\end{array}$ & $\begin{array}{c}-3.655^{* * *} \\
(0.117) \\
\end{array}$ & $\begin{array}{c}-0.570^{* *} \\
(0.177) \\
\end{array}$ \\
\hline High*Car & $\begin{array}{c}1.876^{* * *} \\
(0.110)\end{array}$ & $\begin{array}{l}1.938 * * * \\
(0.098)\end{array}$ & $\begin{array}{l}-0.062 \\
(0.147)\end{array}$ \\
\hline High*Public Tr. & $0^{\mathrm{a}}$ & $0^{\mathrm{a}}$ & $0^{\mathrm{a}}$ \\
\hline $\begin{array}{l}\text { RetAttractiveness*CompEntropy: } \\
\text { Low*City>Periph. }\end{array}$ & $\begin{array}{l}-0.678^{* * *} \\
(0.106)\end{array}$ & $\begin{array}{l}-0.865 * * * \\
(0.094)\end{array}$ & $\begin{array}{c}0.187 \\
(0.141)\end{array}$ \\
\hline Low*City $<$ Periph. & $0^{\mathrm{a}}$ & $0^{\mathrm{a}}$ & $0^{\mathrm{a}}$ \\
\hline High*City $>$ Periph. & $\begin{array}{c}-1.091 * * * \\
(0.169) \\
\end{array}$ & $\begin{array}{c}-0.973 * * * \\
(0.139) \\
\end{array}$ & $\begin{array}{l}-0.118 \\
(0.219)\end{array}$ \\
\hline High $*$ City $<$ Periph. & $0^{\mathrm{a}}$ & $0^{\mathrm{a}}$ & 0 \\
\hline $\begin{array}{l}\text { RetAttractiveness*Basket size: } \\
\text { Low*Smaller }\end{array}$ & $\begin{array}{c}-0.523 * * * \\
(0.061)\end{array}$ & $\begin{array}{c}-0.627 * * * \\
(0.063)\end{array}$ & $\begin{array}{c}0.104 \\
(0.088)\end{array}$ \\
\hline Low*Bigger & $0^{\mathrm{a}}$ & $0^{\mathrm{a}}$ & $0^{\mathrm{a}}$ \\
\hline High*Smaller & $\begin{array}{c}-1.015^{* * *} \\
(0.099) \\
\end{array}$ & $\begin{array}{c}-0.887 * * * \\
(0.085) \\
\end{array}$ & $\begin{array}{l}-0.128 \\
(0.130)\end{array}$ \\
\hline High*Bigger & $0^{\mathrm{a}}$ & $0^{\mathrm{a}}$ & $0^{\mathrm{a}}$ \\
\hline
\end{tabular}

Note: $* * *$ Significance below $0.001, * *$ Significance below $0.01,{ }^{*}$ Significance below 0.05

${ }^{\mathrm{a}}$ : Redundant level ${ }^{\mathrm{b}}: \sigma_{\mathrm{d}}=\sqrt{\sigma_{\theta 1}^{2}+\sigma_{\theta 2}^{2}}$ 